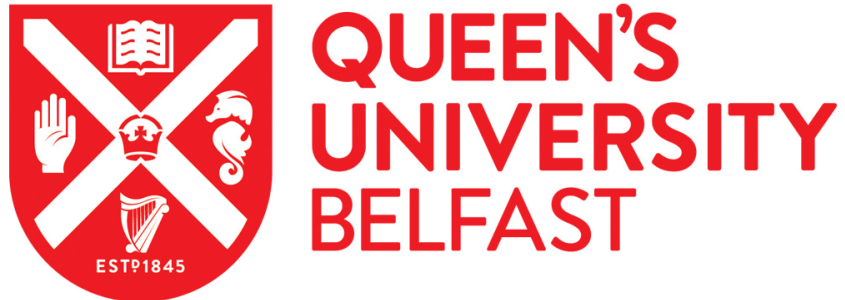

\section{Translational Research: An Oral Historical Timeline from Architecture and Cinema to Migration}

Kacmaz Erk, G. (2020). Translational Research: An Oral Historical Timeline from Architecture and Cinema to Migration. International Journal of Community Diversity. https://doi.org/10.18848/2327-0004/CGP/v20i02/33-48

Published in:

International Journal of Community Diversity

Document Version:

Publisher's PDF, also known as Version of record

Queen's University Belfast - Research Portal:

Link to publication record in Queen's University Belfast Research Portal

\section{Publisher rights}

Copyright 2021 the authors.

This is an open access article published under a Creative Commons Attribution-NonCommercial-NoDerivs License

(https://creativecommons.org/licenses/by-nc-nd/4.0/), which permits distribution and reproduction for non-commercial purposes, provided the author and source are cited.

\section{General rights}

Copyright for the publications made accessible via the Queen's University Belfast Research Portal is retained by the author(s) and / or other copyright owners and it is a condition of accessing these publications that users recognise and abide by the legal requirements associated with these rights.

\section{Take down policy}

The Research Portal is Queen's institutional repository that provides access to Queen's research output. Every effort has been made to ensure that content in the Research Portal does not infringe any person's rights, or applicable UK laws. If you discover content in the Research Portal that you believe breaches copyright or violates any law, please contact openaccess@qub.ac.uk. 
The International Journal of

\section{Community Diversity}

\section{Translational Research}

An Oral Historical Timeline from

Architecture and Cinema to Migration 
THE INTERNATIONAL JOURNAL OF

COMMUNITY DIVERSITY

https://ondiversity.com

ISSN: 2327-0004 (Print)

ISSN: 2327-2147 (Online)

https://doi.org/10.18848/2327-0004/CGP (Journal)

First published by Common Ground Research Networks in 2020 University of Illinois Research Park

2001 South First Street, Suite 202

Champaign, IL 61820 USA

$\mathrm{Ph}:+1-217-328-0405$

https://cgnetworks.org

The International Journal of Community Diversity

is a peer-reviewed, scholarly journal.

\section{COPYRIGHT}

(C) 2020 (individual papers), the author(s)

(C) 2020 (selection and editorial matter)

Common Ground Research Networks

\section{(우(1) $\odot$}

Some Rights Reserved

Public Licensed Material: Available under the terms and conditions of the Creative Commons

Attribution-NonCommercial-NoDerivatives 4.0 International Public License (CC BY-NC-ND 4.0). The use of this material is permitted for non-commercial use provided the creator(s) and publisher receive attribution. No derivatives of this version are permitted. Official terms of this public license apply as indicated here: https://creativecommons.org/licenses/by-nc-nd/4.0/legalcode

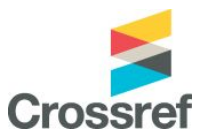

Common Ground Research Networks, a member of Crossref
EDITOR

Eugenia Arvanitis, University of Patras, Greece

ACTING DIRECTOR OF PUBLISHING

Jeremy Boehme, Common Ground Research Networks, USA

MANAGING EDITOR

Helen Repp, Common Ground Research Networks, USA

\section{ADVISORY BOARD}

The Advisory Board of the Diversity Research Network recognizes the contribution of many in the evolution of the Research Network. The principal role of the Advisory Board has been, and is, to drive the overall intellectual direction of the Research Network. A full list of members can be found at

https://ondiversity.com/about/advisory-board.

\section{PEER REVIEW}

Articles published in The International Journal of Community Diversity are peer reviewed using a two-way anonymous peer review model. Reviewers are active participants of the Diversity Research

Network or a thematically related Research Network. The publisher, editors, reviewers, and authors all agree upon the following standards of expected ethical behavior, which are based on the Committee on Publication Ethics (COPE) Core Practices. More information can be found a

https://cgnetworks.org/journals/publication-ethics.

\section{ARTICLE SUBMISSION}

The International Journal of Community Diversity

publishes biannually (June, December).

To find out more about the submission process, please visit

https://ondiversity.com/journals/call-for-papers.

\section{ABSTRACTING AND INDEXING}

For a full list of databases in which this journal is indexed, please visit https://ondiversity.com/journals/collection.

\section{RESEARCH NETWORK MEMBERSHIP}

Authors in The International Journal of Community Diversity are members ofthe Diversity Research Network or a thematically related Research Network. Members receive access to journal content. To find out more, visit

https://ondiversity.com/about/become-a-member.

\section{SUBSCRIPTIONS}

The International Journal of Community Diversity is available in electronic and print formats. Subscribe to gain access to content from the current year and the entire backlist.

Contact us at cgscholar.com/cg_support.

\section{ORDERING}

Single articles and issues are available from the journal bookstore at https://cgscholar.com/bookstore.

\section{HYBRID OPEN ACCESS}

The International Journal of Community Diversity

is Hybrid Open Access, meaning authors can choose to make their articles open access. This allows their work to reach an even wider audience, broadening the dissemination of their research. To find out more, please visit

https://cgnetworks.org/journals/hybrid-open-access.

\section{DISCLAIMER}

The authors, editors, and publisher will not accept any legal responsibility for any errors or omissions that may have been made in this publication. The publisher makes no warranty, express or implied, with respect to the material contained herein. 


\title{
Translational Research: An Oral Historical Timeline from Architecture and Cinema to Migration
}

\author{
Gul Kacmaz Erk, ${ }^{1}$ Queen’s University Belfast, UK
}

\begin{abstract}
This article is about the in-between state that researchers may find themselves in if/when they move from one area of research to another. It is a chronological oral history, an academic diary if you like, of such a time period experienced by an architect who moved from film studies toward migration studies as well as a recent aftermath of this translational research. Via revisiting the researcher's experiences, the article explores possible commonalities, especially for those who go into areas with a high degree of social consciousness. The study pursues which fragments of the old are translatable into the new and vice versa.
\end{abstract}

Keywords: Translational Research, Academic Research, Research Process, Forced Migration, Refugee Crisis, Divided Communities, Architecture and Cinema

[T]o some degree all great texts contain their potential translation between the lines.

Walter Benjamin

Things do not get lost in translation, but they get multiplied through displacement and replacement. And based on the specific story of this transfer in each particular case, the places of departure and arrival of each transportation-which are both already constantly changing with the continuing translation processes-are connected to each other in a unique way. In this way, translations make history.

Esra Akcan

$\mathrm{I}$

$\mathrm{t}$ all started less than three years ago with an email. Alan Chandler from University of East London contacted me about a project UEL and METU (Middle East Technical University in Ankara) would be leading later that year. Since the beginning of the war in 2011, large groups of Syrians were crossing the border in the southeast of Turkey, and as a migrant, I was deeply concerned about their wellbeing and integration in their new community. I was also concerned about the locals, the Turkish people, as migrant numbers went up to millions within a few years. As to the UNHCR records, there are more than 3.5 million registered Syrians in Turkey (UNHCR 2020). For a while, I had been thinking about how to help. When I received the email from UEL, I had a moment of clarity that was exceptionally enlightening. My contribution could be-should be-academic. But how does a scholar do that? How, after more than twenty years, does one move from one area of research (architecture and cinema, in my case) into another (architecture and migration)? I could start with learning and then sharing.

In his "Foreword: Migration is Related to Happiness" in Leaving this Country, Ibrahim Sirkeci talks about finding Turkey's lack of interest in migration surprising since he started to work on the topic in the 1990s. Syrians migrated to Turkey in the 2010s and everybody, shopkeeper and professor alike, he writes, became an expert on migration (Kazaz and Mavituna 2018). I am the scholar Sirkeci gently teases in his text. I am not an expert in a million years,

\footnotetext{
${ }^{1}$ Corresponding Author: Gul Kacmaz Erk, David Keir Building, Stranmillis Road, Architecture, SNBE, Queen's University Belfast, BT9 5AG, Northern Ireland, United Kingdom. email: g.kacmaz@qub.ac.uk
} 
but I now work on architecture and forced migration. Since 2017, I have devoted most of my research time to understanding the refugee crisis in Turkey and elsewhere.

The project in Ankara was an eye-opener, and other work around the themes of forced displacement, refugee crises, and divided communities followed. Having lived in five different countries, I always had a devotion to migration. Academically, this interest was limited to (1) my research on the work of Turkish German director Fatih Akin, who portrayed migrants vividly in his fiction films based in Hamburg and Istanbul (conference presentations and a journal article with Tuna Yilmaz entitled "Fatih Akin Filmlerinde Gercekligin Temsili" [Representing Reality in Fatih Akin Films], Kacmaz and Yilmaz 2014), and (2) the doctoral work of two students, Didem Gunes Yilmaz (2015) on the effects of post-disaster housing after displacement in Eastern Turkey, and Aisling Shannon Rusk (2019) on liminal spaces of divided communities in Northern Ireland (NI) and Israel/Palestine. This changed with the Syrian war, and, as stated above, with an email received on a Wednesday afternoon on May 31, 2017 at 14.59. This is a twenty-eight-month research timeline, oral history if you like, between May 31, 2017 and September 30, 2019.

The study demonstrates how I moved from one area of research (architecture and cinema) to another (architecture and migration) and how I brought these unrelated areas together. This transition will be discussed via Esra Akcan's (2012) concept of translation to draw outcomes from my translational research and in an attempt to generalize some of the empirical findings. Translational research is a term mostly uttered in medicine (since 1993 in cancer research) for the process that implements nonclinical research results in clinical applications, also referred as "bench to bedside." National Cancer Institute, USA defines it as "the process by which the results of research done in the laboratory are used to develop new ways to diagnose and treat disease." ${ }^{2}$ In "Defining Translational Research: Implications for Training," Doris McGartland Rubio and her colleagues (2010) advocate for a wider and multidirectional definition that suggests translations between basic, laboratory-based/nonclinical, patient-oriented/clinical and/or population-based research to improve any aspect of public health care in relation to medical needs.

Dealing with architectural translations between geographical locations (Germany and Turkey), Akcan discusses the concept of translation in Architecture in Translation as follows: "bi- and multilateral international transportations of people, ideas, technology, information, and images generates processes of change that I am defining as translations" (Akcan 2012, 3). This article is about how information, ideas and methods are or can be translated. "The definition of translation includes any act of changing from one place, position, condition, medium, or language" (Akcan 2012, 7). She sees "the foreign as the rejuvenating force, rather than a threat" (Akcan 2012, 4), and looks for what transforms/alters/mutates during translation, what is translatable/untranslatable and refers to civilization, for instance, as translatable while culture being harder to translate. These are cross-disciplinary conversations/interactions/exchanges, so the translations happen both ways, a feature that I also experience in my translational research. For me, contrarily, translation has not been a goal but a tool, a path (Akcan 2012).

The act of translation is questioned most in literary works rather than architectural texts. Translation specialists hold a broad spectrum of opinion about literary translation-one side of the spectrum going toward word-to-word translation with the aim of remaining true the original (fidelity to language), and the other side towards the aim of capturing the effect or essence of the text (fidelity to meaning). Walter Benjamin's approach, as discussed in "The Task of the Translator" (first published in 1923 for his translation of Baudelaire's Tableaux Parisiens then in Illuminations), may be considered more on the latter side of the spectrum: "the task of the translator consists in finding that intended effect [Intention] upon the language into which he is translating which produces in it the echo of the original" (Benjamin 1999, 77). He states: "the word Brot means something different to a German than the word pain to a Frenchman, that

\footnotetext{
${ }^{2}$ https://www.cancer.gov/publications/dictionaries/cancer-terms/def/translational-research
} 
these words are not interchangeable for them; [...] meaning is never found in relative independence, as in individual words or sentences; rather, it is in a constant state of flux" (Benjamin 1999, 75). Therefore, the translator's job is the "reproduction of meaning" (Benjamin 1999, 78) by seizing the intention of the original in the new version: "the translation must be one with the original in the form of the interlinear version, in which literalness and freedom are united" (Benjamin 1999, 82).

The main question here then is related to translatability, a term both Akcan and Benjamin refer to: Can any aspect of academic research be translated from area A to area B? If yes, what and how? And what is translational research anyway? From an architectural perspective, which hopefully will be translated into other disciplines and improved, translational research can be defined as the process of transferring knowledge and methodology created in one area of research into another to benefit from them in a transformed way in both areas. Let us grasp the concept and see how deep the rabbit hole might go for a translational researcher.

\section{7}

June. Before the call for the UEL-METU project that is mentioned above, I was already working on a new initiative, a public engagement project, as part of the CACity (Cinema and Architecture in the City) ${ }^{3}$ Collaborative Research Group I established in Queen's University Belfast (QUB) in 2014. This project is called Walled Cities, a film season organized in collaboration with the Queen's Film Theatre (2017) to bring academics and the general public together. QFT is a cinema that includes non-mainstream and indie (independent) films into their program. Walled Cities started to exhibit films that were about divided communities, and the physical and social implementations of the partition. The films in the first season portrayed the West Bank (Israel/Palestine in Omar), Belfast (NI in '71) and West Berlin (West Germany in Wings of Desire). The screenings took place at 6 p.m., each in a different week, starting with a short introduction before the film and was followed by a discussion with two experts and the audience. Over the years we have had architects, planners, geographers, film directors, political scientists, engineers, etc., as guest speakers as outlined below in Table 1. As much as possible, we tried to bring together two people who could represent both sides of the divided community portrayed in the films. The conversation continued in the foyer of the theatre over a wine reception.

Table 1: Walled Cities Filmography (in order of screening).

\begin{tabular}{|l|l|l|}
\hline \multicolumn{1}{|c|}{ Film } & \multicolumn{1}{c|}{ Place (set/shot) } & \multicolumn{1}{c|}{ Guest Speakers } \\
\hline \multicolumn{2}{|c|}{ Walled Cities 1 } & \multicolumn{1}{c|}{$\mathbf{2 0 1 7}$} \\
\hline $\begin{array}{l}\text { Omar } \\
\text { Hany Abu-Assad, 2013 }\end{array}$ & $\begin{array}{l}\text { West Bank in } \\
\text { Palestine/Israel }\end{array}$ & $\begin{array}{l}\text { Merav Amir, QUB Geography } \\
\text { Mazen Iwaisi, QUB School of History, } \\
\text { Anthropology, Philosophy and Politics }\end{array}$ \\
\hline $\begin{array}{l}\text { '71 Yann Demange, 2014 } \\
\text { Wings of Desire }\end{array}$ & Belfast (shot in & $\begin{array}{l}\text { Frank Gaffikin, QUB Planning } \\
\text { Een Sterrett, QUB Planning }\end{array}$ \\
\hline Wim Wenders, 1987 & West Berlin & $\begin{array}{l}\text { Liat Savin Ben-Shoshan, Bezalel Academy of } \\
\text { Arts and Design } \\
\text { Gul Kacmaz Erk, QUB Architecture }\end{array}$ \\
\hline
\end{tabular}

\footnotetext{
3 CACity Collaborative Research Group. "Cinema and Architecture in the City." Accessed May 16, 2020. https://www.cacity.org.
} 


\begin{tabular}{|c|c|c|}
\hline Walled Cities 2 & & 2018 \\
\hline $\begin{array}{l}\text { The Legend of Paul and } \\
\text { Paula } \\
\text { Heiner Carow, } 1973\end{array}$ & East Berlin & $\begin{array}{l}\text { Tanja Poppelreuter, University of Salford } \\
\text { Architectural History } \\
\text { Gul Kacmaz Erk, QUB Architecture }\end{array}$ \\
\hline $\begin{array}{l}\text { Walls, Pablo Iraburu and } \\
\text { Migueltxo Molina, } 2015\end{array}$ & $\begin{array}{l}\text { USA-Mexico, } \\
\text { Morocco-Spain, } \\
\text { Zimbabwe-S.Africa }\end{array}$ & $\begin{array}{l}\text { Murat Akser, University of Ulster Cinematic } \\
\text { Arts } \\
\text { Ulrike Vieten, QUB Mitchell Institute }\end{array}$ \\
\hline $\begin{array}{l}\text { Akamas } \\
\text { Panikos Chrissanthou, } \\
2006\end{array}$ & Cyprus & $\begin{array}{l}\text { Evropi Chatzipanagiotidou, QUB } \\
\text { Anthropology } \\
\text { Satish Kumar, QUB Geography }\end{array}$ \\
\hline Walled Cities 3 & & 2019 \\
\hline $\begin{array}{l}\text { Earth } \\
\text { Deepa Mehta, } 1998\end{array}$ & $\begin{array}{l}\text { Lahore, now in Pakistan } \\
\text { (shot in New Delhi, } \\
\text { India) }\end{array}$ & $\begin{array}{l}\text { M. Satish Kumar, QUB Geography } \\
\text { Wasif Naeem, QUB School of Electronics, } \\
\text { Electrical Engineering, Computer Science }\end{array}$ \\
\hline $\begin{array}{l}\text { Death in Sarajevo } \\
\text { Danis Tanovic, } 2016\end{array}$ & Sarajevo & $\begin{array}{l}\text { Colin Hall-Thompson, Remembering } \\
\text { Sebrenica Group } \\
\text { Jelena Vlajic, QUB Management }\end{array}$ \\
\hline $\begin{array}{l}\text { Mickybo and Me } \\
\text { Terry Loane, } 2004\end{array}$ & Belfast & $\begin{array}{l}\text { Terry Loane, director of the film } \\
\text { Gul Kacmaz Erk, QUB Architecture }\end{array}$ \\
\hline
\end{tabular}

August. As I was getting ready for the UEL-METU project in Ankara (and the drawing workshop I proposed with Syrian children), I reflected on what I could do in this area of research. I had to combine what I already knew (architecture, cinema) with what I was learning (migration, minority studies). The old would support the new. With colleagues from creative arts, mental health studies and architecture, we applied for funding for an urban filmmaking workshop (and focus groups around the workshop) for Syrian refugees living in Istanbul. I do organise urban filmmaking workshops for the community but not specifically for refugees. The call was for a Global Challenge Research Fund (GCRF) by the Department for the Economy. Sadly, we did not get the funding.

September. In the meantime, I took another step and shifted the theme of my master humanities dissertation group from "architecture and cinema" to "architecture and forced migration" and named the group "Odd One Out." I was certainly out of my comfort zone in this first attempt while supervising fifth-year students. Having said that, new beginnings are full of enthusiasm. This group consisted of local master students passionate about the architectural conditions of refugees in cities and camps in Ireland and Britain as well as Canada, Japan, and Jordan. The concept of home, temporary versus permanent, inclusion, and activist art were preferred topics. Ciara Mitchel's dissertation (2018) about the direct provision centers for asylum seekers in the Republic of Ireland won the Postgraduate Writing Prize in Queen's Architecture. These were the dissertations written in the 2017-2018 academic year:

Odd Ones Out's dissertations

- Architecture of Asylum: Ireland's Direct Provision Centres

- Architects of Revolution: Urban Activism, Asylum Seekers, and the Politics of Fear in the UK

- Newcomer Adaptions within a Diverse Community: Architecture Solutions in Canada

- $\quad$ Refugee Camps: Permanent Cities in the Making? (Zaatari, Jordan)

- Shelter to House to Home: The Role of the Architect in Humanitarian Relief (Japan) 
"We believe that everyone has the right to benefit from architecture." This statement from the press release of Yvonne Farrell and Shelley McNamara (2017) started to appear in my new research as early as September 2017, three months after Dublin-based Grafton Architects announced their plans for the Venice Biennale. I started questioning how we could include forcefully displaced people into "everyone" and what the role of the architect might be in the incorporation of refugees into the public realm. There are not a handful of them; the number of displaced people worldwide has exceeded 70 million (UNHCR 2019). So how can they claim their right to benefit from architecture? Is that even possible?

October. We applied for funding again for the urban filmmaking workshop with Syrian refugees in Istanbul, this time through the British Academy. We did not get it-again. This was really disappointing but did not change my ambition to go into a new area of research. For the time being, I stopped looking for funding in this area. I needed more experience and presence in migration studies. The trip to Ankara would be an ideal start.

October. After the email in May, I applied for participating in the UEL-METU project in June and got accepted. Project coordinators Alan Chandler, UEL and Ela Alanyali Aral, METU were inviting seventeen researchers from Turkey and seventeen from the UK. My mother was disappointed when she heard I was part of the British team. At the time we did not know most of the UK participants would be international people, researchers and artists from Europe and the Middle East.

The joint research project, Cities in Transition: Locality, Identity and Experience of Place, was funded by British Council and Newton Fund. It took place in the School of Architecture at METU in the capital city of Turkey. This was the university where I studied for my bachelor's and master's degrees of architecture for six years back in the 1990s. Behruz Cinici's Faculty of Architecture building and METU campus were constructed in Modernist style in the early 1960s and were an inspiration to multiple generations of design and planning students.

There were about 50,000 Syrians at the time in the municipality of Altindag in Ankara. This district was in the process of urban renewal, and there were various empty buildings waiting to be demolished. Altindag was also close to the furniture industry in Siteler. Our work took place mainly in this district and at METU. Our lavish meals, a reflection of Turkish hospitality, did contradict with the poor conditions in Altindag. It was disorienting to work with vulnerable people. It affected me; it affected all who participated.

One of the highlights of the weeklong study was the workshop we conducted with Syrian children in ASAM, Solidarity with Asylum Seekers and Migrants, ${ }^{4}$ a non-governmental institution (NGO) in Altindag. There were two other workshops run with Syrian women, one about proverbs and one about daily life. Ours was entitled Drawing as Communication: A Workshop with Syrian Children in Turkey. Through play and drawing, we tried to connect with the (primary school) children and talk about the spaces and places they lived in Ankara and back in Syria. Though we had an interpreter, the fact that I could speak with most of the children in Turkish was beneficial since several workshop tutors were interacting with them simultaneously. Both the workshop and the visit to the NGO were memorable events. The building, unlike the office and storage space of the Turkish Red Crescent ${ }^{5}$ in the same area, was surrounded with a fence, and, even in the garden, the differences in appearance between the (male and female) academics and Syrian women waiting to be invited in were noticeable. ASAM was like a Syrian embassy and locals, Turks who live in the area, would probably not

\footnotetext{
${ }^{4}$ Solidarity with Asylum Seekers and Migrants. "SGDD [ASAM] Ankara Altindag Representation.” Accessed May 16, 2020. https://sgdd.org.tr/where-we-work/\#ANKARA.

${ }^{5}$ Turkish Red Crescent. "Kizilay Altindag Subesi” [Turkish Red Crescent Altindag Branch]. Accessed May 16, 2020. https://kizilay.org.tr/Subeler.
} 
feel welcome, though they would very much be welcome there. Some of the outcomes of Cities in Transition (2017) were as follows:

1. Make use of what you already know and what you are interested in.

2. Networking is one of the key outcomes, as in any cross-disciplinary collaborative project. You find the right people to work with in the future.

3. There is no researcher and researched subject in migration/minority studies. We are all participants. You participate, and learn, as much as the refugees.

The significance of the work we conducted in Ankara for my architectural transition from cinema towards migration should be acknowledged. As you will read below, Cities in Transition has been a milestone for my research as an academic.

\section{8}

January. I presented my work and experiences in Ankara in the All-Ireland Architecture Research Group (AIARG) conference held at Queen's University in Belfast. This was the first time I put together a scholarly presentation on architecture and migration. It certainly was different from presenting on cinematic spaces. To begin with, I had to refer to a great deal of statistical data that had to be up to date. Research via non-academic sources such as (official) websites and newspapers were important sources of information. The most striking aspect for the Irish audience was the numbers. The numbers of displaced Syrians in general and of the ones who managed to go to Turkey were so high that it was hard not to react to them. After my experience in Ankara, some of my proposals about the architectural needs of refugees for sustainable co-habitation that I discussed in AIARG were the following:

Action projects

- Shared communal spaces for Turks and Syrians (kahve for men and a community centre for all)

- A space for skills exchange for Turkish and Syrian women

- Youth centre (for teenaged Turks and Syrians)

Academic contribution

- Research documenting the existing situation in Syrian neighbourhoods (data and survey drawings to support the government and NGOs) - Who is where? In which condition?

- Live studio/art projects set for Syrians, and for Turks and Syrians

- Participatory research to analyse architectural/urban needs of refugees and the role of public space in the integration process (This last item is my focus.)

February. As Odd One Out master group, we entered the international IDeA competition that is specifically about refugees. This US-based competition had three sites; we chose the one in Africa for our proposal, and designed a mobile food facility, Matatu Meals, shared by locals and refugees to prepare and eat food together in Nairobi, Kenya. As described: "the scheme hopes to create bonds between the refugees and the locals living in Nairobi. Through the share act of cooking and eating the proposal will create an interactive platform for locals to interact with refugees throughout the city and experience the culinary influence of a different culture. An important aspect of the proposal in promoting dignity and normalcy amongst the refugees with the right to work, learn and socialise all in the same urban landscape" (IDeA 2018). The project was one of the seventeen finalists out of more than 200 entries and awarded an honorable mention.

March. Walled Cities 2 film season started in March, with two fiction films based in East Berlin (East Germany in The Legend of Paul and Paula) and Akamas (Cyprus in Akamas), and 
a documentary with various borders around the world (borders between Spain and Morocco, Mexico and the United States, and South Africa and Zimbabwe in Walls). (Please see Table 1 for details.) Though I favor fiction films for the Walled Cities, Walls was a powerful narrative of barriers built between the first and the third world and a good fit for the film season.

April. As we were pursuing Walled Cities 2, I was writing a conference paper entitled Cinema and the Walled City (Kacmaz Erk forthcoming) about the films exhibited in the first season. As explained in the abstract:

Film space is a representation of urban space. To benefit from the representational images of a city to build its portrait, one can explore the immaterial reconstruction of cities in film. Does this argument fail though, if the urban area portrayed in the film is a walled city? Can the film director ignore or overcome the physical (and mental) division defined by impenetrable walls in urban scale? This study aims to raise these questions focusing mainly on Belfast "peace" walls in Northern Ireland, Berlin wall in Germany, and West Bank wall in Palestine/Israel. (Amps 2018)

I presented this research in the fourth Amps Mediated City conference in Istanbul. The paper was then selected for an edited book, and the longer version is accepted as a book chapter in October 2018. Following the review process, the final version is approved in August 2019. The book is expected to come out in November 2020. It usually takes a long time to publish, in this case two and a half years.

August. As I was preparing for a project in Istanbul, I attended the Global Conflict: The Human Impact Conference organized by the Senator George J. Mitchell Institute for Global Peace (2018), Security and Justice, QUB, and Pearson Institute for the Study and Resolution of Global Conflicts, the University of Chicago. The conference aimed "to bring together policy leaders, academics and practitioners 20 years after the Good Friday Agreement to examine lessons learned from the peace agreement and identify emerging strategies for conflict resolution" (Mitchell Institute 2018). The conference presentations, one by George Mitchell himself, and my coffee break with an EU representative were an eye-opener, especially to "locate" Turkey in the big picture of the chaotic refugee crisis worldwide.

September. We had a small amount of money left from Walled Cities 2 films and decided to do a "pilot study" with minimal budget in Istanbul to test some of the ideas about the urban filmmaking workshop I was planning with refugees. I invited film scholar Murat Akser, University of Ulster, to join me. We scheduled the trip for September. Neither this study nor any of the Walled Cities film events would be possible without the support of Culture and Society research cluster in the School of Natural and Built Environment at Queen's. In 2016, two schools merged to form the SNBE, and three research clusters are formed to promote crossdisciplinary work within the school. Accordingly, I got the chance to collaborate with the other disciplines, particularly the geographers and planners (for instance, via the Speculative Spaces reading group we established in 2017). The challenge with starting something from scratch, in this case research, is that almost everything is new. Therefore, I developed strategies and ground rules:

- Admit and accept that you are new at this.

- Approach it with caution but be brave. Make good use your years of experience as a researcher. Include your previous/established work.

- Find the right tools to learn new methods and literature as quickly as possible via literature review, archival study, conference participation, networking, field work, etc.

- Collaborate with experts. 
I planned the weeklong pilot study (and the future workshop) in Istanbul accordingly. I was new in migration studies but not in architecture and film. I chose a project that included my expertise in urban filmmaking and workshop coordination; I chose a location that I am familiar with and that I can speak the language of; I contacted people already working with refugees, and I reached out to all the experts, activists and friends who might be interested in participation.

The study, which is the 'trial and error phase' of a larger practice-based participatory research project, tests the scholars' ideas about the refugees' 'lived spaces' including their homes, streets, workplaces, as well as the places they go for education, shopping and leisure. Carried out with refugees who are amongst 3,5 million registered Syrians in Turkey, the study uses filmmaking to understand and share their architectural/urban needs and challenges in Istanbul. (Kacmaz Erk 2018)

This was the synopsis of the pilot study. Our plan was to do some shooting with young refugees in Balat, Fatih which was the proposed location in Istanbul for the actual workshop, to meet experts in the area, video interview them and refugees if possible. Accordingly, we conducted the following research methods in Balat from Monday to Friday.

- Observation, field notes, photography

- Urban filmmaking and photography (by refugees) and their review (for the purpose of training)

- Site visits (homes and neighbourhoods of refugees)

- Meetings with experts for networking

- Video interviews (academics, NGOs and refugees)

The highlight of the week was meeting and working with some of the Syrian refugees in Fatih. I had already started to recognize in Ankara that in migration studies you are a participant just like the refugees, so seeing myself in action and reflecting on my weeklong experience was invaluable. The second gain was getting to know the situation better via the expertise of academics, NGO representatives and activists. Trust is key in this kind of activity, and I not only learned from the people 'on the ground' but also hopefully gained their trust. This was true for my encounter with the Syrians as well.

This was an emotionally intense experience for me. I was in Balat during the day and was having quiet evenings to heal. Although I was in a city full of friends and attractions, a city I always missed as a gurbetci, an expat, I was going straight to my sister's home and playing with my nieces. The huge gap between the lives of the refugees and my family was disorienting. Having said that, that was more of a socio-economic issue rather than "local versus newcomer." I would probably feel the same way if my research was about working-class Turkish people in Balat. Turks and Syrians (and Romans) do live together in this historical part of the city in constant interaction with one another.

The pilot study was beneficial to my ongoing training in and translation towards forced migration. It also helped us reshape the future workshop. Despite my experience in the "west," we now know that one week will not be enough to train refugees about shooting and editing a short film, so we are planning a two-week summer school. It will not be solely for young Syrians (ages 16-26) but also Turkish university students. They will team up to make urban films; this will hopefully generate inclusiveness. The participants will be paid for their time as they will not be able to work during the summer school. This fee, even small, is very important for the Syrians. For one or two exceptional participants, we will try to secure an internship in photography or the film industry before the workshop.

September. Upon my return, I called the new master dissertation group "Activist Architects." We continued working on architecture and forced migration focusing on the future 
of migrants and diversity in architecture. Unlike the previous year, the students were all international (from Europe and Africa), and they chose to work on camps and refugee accommodation with diverse case studies and focus. These were the dissertations written by the Activist Architects in the 2018-2019 academic year:

Activist Architects' Dissertations

- Architecture for Healing and Adaptation: Wellbeing and Social Support Infrastructure in Refugee Camps

- From Shelter to Home: Integration of Refugees through Architecture in Germany

- People of Nowhere: Living in Temporary Cities on a Permanent Basis

- Where is Home? The Architecture of Refugee Camps: The Case of the Northern Coast of France

\section{9}

January. As I was working with the Activist Architects, the previous year's Odd Ones Out presented their research collectively in the So What? Making Research Public series organized by $\mathrm{PLACE}^{6}$ in the city center of Belfast. PLACE is an important non-profit organization in Northern Ireland delivering creative projects that connect people to the built environment and lived spaces. This was a good experience for the students who were now in their final year in the master program. It also created awareness about the refugee crisis worldwide. Unfortunately, this not-for-profit organization could not receive funding from the Arts Council this year and had to close its doors by the end of August 2019. This has been a huge loss for the community.

January. In the next AIARG conference held in Dublin, just a few months after the project, I presented the pilot study we completed in Istanbul in a room full of architects. Going through the footage, photographs and the interview notes was an interesting experience and reflection. Again, the severity of the situation as I presented the statistics was overwhelming for the audience. Seeing Istanbul through the lens of a Syrian adolescence provided direct information about the living spaces of these people under "temporary protection" and did evoke empathy.

June. I presented the pilot study in a different way in the International Diversity Conference in Patras, Greece, ${ }^{7}$ four months later. Unlike AIARG Dublin, to my knowledge, there were no architects in this conference. Before going, I thought everybody would already know everything about the Syrian war and the refugee crisis there. The special focus of the conference was "Border Crossing Narratives: Learning from the Refugee Experience." I was wrong. My talk was on the third and last day of the conference and I planned to change my presentation as to the profile of the participants. I ended up not taking much out for a few reasons:

- The conference, though its focus was the refugee crisis, did not only include topics and talks about displaced people but also ethnic minorities, people with disabilities, LGBT+, religious minorities, class divide, etc. Therefore, not everyone knew much about migration.

- We were in Greece and there were several Greek presenters in the conference who shared their research about the Syrian refugees. It was interesting to see that the majority of these scholars did not know much about the refugee situation in Turkey on the other side of the Aegean Sea.

\footnotetext{
${ }^{6}$ PLACE Built Environment Centre. So What? Making Research Public. Accessed May 16, 2020. http://www.placeni.org/so-what.html.

${ }^{7}$ https://ondiversity.com/about/history/2019-conference
} 
It is important to state that hearing about other disadvantaged minority groups in this conference was highly beneficial to my research. The literature covered, the terminology, discussions around shared concepts like identity and belonging were helpful to further my studies. When talking about disadvantaged or vulnerable people, one needs to be extremely careful about using the right words to explain their situation and conditions.

How I ended up in this conference is an interesting anecdote as I did not apply for it. I sent my abstract to the Arts in Society Conference of Common Ground Research Networks, which is a US-based not-for-profit corporation. I had attended CG's Arts and Humanities conferences in the past. They promote interdisciplinary work and cross-institutional collaboration. They also publish several academic journals like the one you are reading (still here I hope). The team of the Arts Conference contacted me saying that my work was better suited to the Diversity conference, and with my permission, passed it on. So instead of going to Lisbon in June, I flew to Athens.

In Patras, I realized that several scholars, researchers, and specialists from various backgrounds and disciplines, be it law, minority studies, social work, or gender studies, do not publish the substantial work they do simply because the way they would like to write their work up does not fit the standard research paper format that is considered established (with a "proper" literature review, long list of references, etc.). Consequently, so much is lost without going into writing/literature and without contributing to knowledge. This article is my attempt to overcome this in my field and maybe be a precedent for others.

June. Walled Cities 3: Divided Communities film season took place with three new films that represented Lahore (India/Pakistan in Earth), Sarajevo (Bosnia/Serbia in Death in Sarajevo) and Belfast (NI in Mickybo and Me). Including female director Deepa Mehta's film to our repertoire was an achievement. Because of copyright issues and availability, we cannot always provide the films we look for. The highlight of the 2019 season was the conversation with Terry Loane, the director of Mickybo and Me, right after the exhibition of his celebrated film. Two, maybe three, generations were present in the cinema theatre that day including my and Loane's family. (Please see Table 1 for details.)

I need to state that everything you have been reading was happening alongside my role as a program director for the BSc Architecture course at Queen's since 2016. I was setting up the new vertical studios between second and third year, helping new staff members to settle in (we had quite a few, about ten, in the last two years) as well as continuing my research on architecture and cinema. These were in addition to my weekly studio tutoring, history-theory lecturing, and master dissertation and doctoral thesis supervision. On the upside, I will be on sabbatical leave in the following academic year.

September. The organizers of the Cities in Transition project in Ankara prepared an outline for a promising edited book entitled Urban Flows: Issues on Changing Urban Space (Erkarslan and Aral, forthcoming). My abstract for a book chapter entitled "Right to a New Home" (Kacmaz Erk forthcoming) was accepted in January. I submitted the full text to editors Ozlem Erdogdu Erkarslan and Ela Alanyali Aral in September. Reviewed and revised already, hopefully the study will be printed in 2021. The chapter focuses on two Syrian families I had the privilege to work with in Fatih, Istanbul, during the pilot study. In the context of forced displacement, I discussed the concept of home in this paper, not as a finalized entity or term but a process, writing about home as space, home as place, home as idea and home as utopia. In the study, I compared two former working- and middle-class families who are now replaced in a host country aiming to emphasize the differences between refugees, and their existence as individuals rather than an abstract concept as "refugee."

As I researched the literature for this article, I realized that there is not much written on "home and displacement" from an architectural point of view. Most of the scholars who work in the fast-growing area of home studies are social scientists such as human geographers, anthropologists and psychologists. Therefore, I intend to continue on the topic to bring the architectural side of things to light. 
September. I presented a new study entitled "Everyday Practices and Lived Spaces of Refugee Children on YouTube" in the CineMuseSpace Conference: Slices of Everyday Lives in the University of Cambridge. Showing the daily lives of four children with diverse pasts and futures, I talked about the significance of, what I call, everyday videos. They:

(1) Encourage identification; they break the barriers between us and them by showing others' everyday lives and space. (2) Prevent generalisation or typification; they show that refugees are human beings; the person in the video who gets on with his/her life could have been you or your child. (3) Enhance familiarity; they show that refugees are not victims but people who want to get on with their lives in a difficult situation. (4) Demonstrate the parallels between the refugee children's challenges, preferences and desires as well as the things that make them happy and help them settle in a new place better. (Kacmaz Erk 2019)

Shortly after the conference, the paper was selected for an edited book by the conference organizers in Cambridge.

September. September had been the wrapping-up period for several (mostly writing) projects after a busy summer. Along with the book chapter and the conference presentation I finished writing the first version of this journal article entitled Translational Research for Common Ground Publishing.

October onward. That brings us to the time of writing as I sit in my local coffee shop in South Belfast with my half-finished cup. What is next? I am on sabbatical leave between September 2019 and August 2020 after teaching/researching/managing at Queen's for almost nine years. When I applied for sabbatical two years ago in July 2017, I did not have a body of work on architecture and migration as you now know. So, my proposal was related to architecture and cinema; a book project co-authored with Florida-based architectural historian Christopher Wilson who introduced me Common Ground more than ten years ago. Our first coauthored article was published by this publisher. The book proposal brings together architecture, urbanism, cinema and memory studies in the context of Berlin in the twentieth century. We have already published a journal article on the topic: "Framed Memories of Berlin: Film, Remembrance and Architecture" in the Journal of Architecture and Culture (Kacmaz Erk and Wilson 2018). The book will focus on the urban strategies implemented in the capital city of Germany, from memorial-making (to remember) to demolition (to forget) and everything inbetween and explore how urbanism and architecture have shaped urban memory in Berlin since 1900. Films made within the city will guide the way and we will certainly keep an eye on the established migrant and refugee situation in Berlin. This project, with two Berlin trips, one residency and a filmmaking workshop already planned, will take up all my time during the sabbatical. Having said that, I am already "squeezing in" publications such as this article.

The goal, upon my return to teaching, is to bring forced displacement into studio tutoring and dissertation supervision. As the project for my Cinematic Architecture Studio, I am planning to propose a building for refugees shared with the local community possibly in Belfast or Istanbul. The new master dissertation group on architecture and forced migration will be called the "Black Sheep."

\section{So What?}

Why did I tell the story of my fairly new research? Which aspect of academic research can be translated from one area to another? How? What can be learned from translational research? We tend to isolate ourselves from our research and writing to such an extent that the researcher who is the reason for all the outputs and has been present at every step of the way disappears. This is 
my attempt to bring the researcher back in as a vital figure of the study. This article attempts to break the barriers between the object (the research paper) and the subject (the author).

One of the things I have learned in the last twenty-eight months is that you are not solely "the researcher" in migration studies and minority studies, especially when you do practicebased participatory work. You are a participant, just like the other participants of your study. This study acknowledges that and brings forth the author as a participant who learns and grows as she researches. Doing so, the article attempts to break the barriers between the researcher and the refugees. This allows a less top-down and more bottom-up approach to research.

In this way, a unique relationship with refugees emerges, which exceptionally may result in new friendships. Some social scientists treat the idea of friendship with suspicion. Referring to those who are concerned, Christina Georgiadou writes "friendship cannot exist but is a rather romantic illusion of the researcher. The unbridgeable [cultural and social] gaps between him/her and the subjects and the utilitarian motives of the researcher make pure friendship unattainable." She disagrees: "we could create intimate relations 'as if' they were my younger brothers." Other scholars worry that friendship misinforms the research, both the process and findings: "deep involvement and familiarity with the informants can obscure his/her perception and judgement, make him/her biased and partial," which Georgiadou opposes stating, "relating and judging are two different processes" (Georgiadou 2013, 122-23).

When we read an article, listen to a conference presentation, or attend a "public engagement" event, we are exposed to one side of the work of the researcher or team of researchers. We do not get the chance to understand how they come from A to B, what feeds into their work along the way, and how different activities influence each other. This article attempts to break these barriers between different projects of a researcher/team to understand translation possibilities.

We are used to expressing rational reasons for doing a particular type of research and for going into a certain area of research. We rigorously explain why we work alone or with collaborators from other disciplines. We tell the world the beneficiaries of our research. We fail to share though some of the subjective reasons for choosing an area or method. We do not write about the big question mark in our minds that bugs us during the day coming back as we sleep. We hide our curiosity maybe thinking it is selfish, or not rigorous. This article attempts to break these barriers between the self and our actions, intellectual and otherwise. This might help to see the translations that take place within the individual.

It is already mentioned that I am a voluntary migrant, an international academic in the West with two nationalities, and have lived in four other countries other than my homeland since 2001. What I have not declared is that my grandmothers and a grandfather were also migrants a century ago. When the Turkish-Greek conflict started in the early twentieth century, they moved from Crete to Western Turkey, from Chania to Foca, Chania to Izmir, and Kandia, today's Iraklion, to Menemen, respectively. They were not forced to leave their homeland-this did not happen until the population exchange in the 1920s-but they anticipated the outcome of the political tension and moved before they had to run away. This does not change the fact that they had to leave their lives behind. I was brought up in a home in which Greek was a second language for the parents/relatives, and our direction at home in Izmir at the far western end of Turkey was toward Greece rather than Turkey's eastern neighbour Iran. Ironically my other grandfather was displaced within Anatolia from Van close to Iran to Izmir (through Karaman, Konya). This was a result of the Turkish-Armenian conflict. Looking back, this might be the reason of my feeling like a nomad and of my personal need to research the refugee situation we are in today.

My individual state in-between architecture-cinema and architecture-migration, and personal attempts to translate some of my know-how into the refugee studies, might be unique to me. However, some of my translations might be common for scholars who dare to come out of their comfort zone, and transit between disciplines by going into an area that is new to them. 
These translations might also be relevant to early career researchers as any scholar starts their work with their background, maybe not in academia but in life. Let me try to point out these commonalities by asking one of Akcan's questions $(2012,6)$ : "How is translation possible in the first place?"

1. If a researcher is moving from area A to B, they are not starting from scratch. They carry with them their background as a person and a scholar. So, they constantly refer to and benefit from area A. This might be somewhat obvious. What is not that obvious is that the new research in area B starts to inform and influence area A from the very beginning. By providing a new perspective into what is familiar, sometimes too familiar, it enriches one's established area of research. Architecture and migration has a refreshing influence when I do research on architecture and cinema. This can be called "backward translation" or "re-translation." Akcan also refers to hybridization $(2012,5)$ and the symbiotic relationship between A and B, as quoted at the beginning of this article. About re-translation, Benjamin writes: "by virtue of its translatability the original is closely connected with the translation; [...] a translation comes later than the original; [it is the] continued life [of the original.] For in its afterlife-which could not be called that if it were not a transformation and a renewal of something living - the original undergoes a change" (Benjamin 1999, 71-73). For instance, when architectural space as the original is translated into film space, it starts to alter.

2. Looking into shared concepts and knowledge transfer is maybe the most fulfilling aspect of translational research. Take the concept of "home." It is interesting to analyze this architectural concept loaded with meaning in the context of a fiction film. Since there is a strong link between a house and its dweller, cinema uses their lived spaces to give the audience clues about and attributes of the protagonists as for instance in the photojournalist's apartment with an interesting view and belongings in Alfred Hitchcock's Rear Window (1954). Doing so, the space turns into the extension of the human body. When you take the concept of home into refugee studies, as I did in "Right to a New Home" (Kacmaz Erk forthcoming), it immediately shifts the focus into other concepts: belonging, attachment, identity and longing.

3. The researcher's comfort zone is not only about the content of the study. It is also about the research environment, collaborators, media and methodology. Each discipline has its conventions and working with film scholars for an architect is significantly different from collaborating with NGOs and refugees. One might not have a sleepless night after talking to a film director but might after visiting the new home of a refugee family. In this context, referring to the former ways of research to distant oneself from the latter slightly might be beneficial to the wellbeing of the researcher.

4. Similarly, cinema takes the architect towards the arts whereas migration takes the architect closer to social sciences. The social (and political) agenda of someone working with refugees is inevitable. As she works with disadvantaged people, the scholar usually starts to transform into an activist. This translation feeds into her academic position. Accordingly, translations start to emerge via the threads connecting the academic and the activist. "It is no easy task to find ways to include our multiple voices within the various texts we create," as bell hooks says $(2015,147)$, yet it is worth a try.

5. The transformation of the researcher into a participant is already mentioned. That is, the research is based less on the evaluation of the material by the researcher as an authority figure, and more on the collaborative development of knowledge by all the participants including the researcher. This translation of power is a significant alteration.

6. My urban filmmaking workshops, which worked intensely but perfectly in the western context from Monday to Friday need to be extended to a two-week summer school for refugees. A research method that may work smoothly in one area needs to be altered for the 
other. As Akcan (2012) explains, translations come with changes, mutations and transformations; there is no direct translation from A to B. In that sense, taking filmmaking as a method that I already use in my research and translating it into video interviews in the pilot study was a deliberate choice. Intertwined methods are rich ingredients for research.

7. And finally, linguistic translations: There are significant differences between working with people and material in a shared language (in my case, English), and not-shared languages (Arabic). When I interact with refugees, I talk in Turkish or English. When the sole language that they speak is Arabic, which I cannot, we get help from an interpreter. Even when I am translating an interview in Turkish into a text in English, two languages I am fluent in, cultural diversities start to emerge, and mutations take place. This is an enriching property of the nature of cross-cultural research, similar to the mediation of cinema as a representational medium in understanding architectural spaces and places. We should be grateful to the art of translation.

As an influential translational historian of our time, Yuval Noah Harari translates history using contemporary scientific knowledge and deciphers stories told since the beginning of humankind. This translated history becomes a new interpretation of the world. In Homo Deus (2016), Harari interprets humanism as the driving "religion" of the nineteenth and twentieth centuries, with liberal, socialist, and evolutionary variations, almost "sects," while he refers to "dataism" as the religion of the twenty-first. In this context, translational research discussed in this article follows an outdated humanist approach as it puts learning, change and growth of the individual (liberal humanism) for the better of the masses (socialist humanism) in its center. It can be argued though, that as translational research implements learning, change, growth and sharing, it produces immense amount of data that feeds into the system dataism thrives with. In this journey, reflection via asking questions is more critical than drafting answers. This is the challenge of learning; one knows less and maybe becomes more vulnerable as they learn. First year architecture students are much braver than sixth years. Confidence and belief in oneself and the work help at uncertain times while doing translational research; it is vital to believe that all the research and researchers affected will improve in this process and afterwards.

Where to from here? In this study, the lived experiences and some of the future plans of a translational researcher are explained. Time will tell where the path will take her and her work. Let us conclude with Johann Wolfgang von Goethe who believes that "the goal of the translation is to achieve perfect identity with the original, so that the one does not exist instead of the other but in the other's place" (Goethe [1819] 1992, 61). He claims:

A translation that attempts to identify itself with the original ultimately comes close to an interlinear version and greatly facilitates our understanding of the original. We are led, yes, compelled as it were, back to the source text: the circle, within which the approximation of the foreign and the familiar, the known and the unknown constantly move, is finally complete" (Goethe [1819] 1992, 63).

\section{Acknowledgement}

I would like to acknowledge my sincere gratitude to Gary Boyd and Keith Lilley for encouraging me to explore a new area of research and supporting the theoretical and practical activities outlined in this article. My appreciation extends to Michael Staley who has supported the film seasons since the beginning and solved all the crises. I will always be thankful to Alan Chandler for emailing me on May 31, in 2017. 


\section{REFERENCES}

Akcan, Esra. 2012. Architecture in Translation: Germany, Turkey and the Modern House. Durham, NC: Duke University Press.

Amps (Architecture_Media_Politics_Society) Research Network. 2018. "Moving Images Static Spaces Conference: Architectures, Art, Media, Film, Digital Art and Design." http://architecturemps.com/istanbul.

Benjamin, Walter. 1999. Illuminations. London: Pimlico.

British Council. 2017. Cities in Transition: Locality, Identity and Experience of Place. https://www.britishcouncil.org.tr/sites/default/files/cities_in_transition_call_for_partici pants_0.pdf.

Farrell, Yvonne, and Shelley McNamara. 2017. Freespace: Venice Biennale Press Release. http://files.cargocollective.com/159426/1.-Press-Release-16.-InternationalArchitecture-Exhibition---La-Biennale-di-Venezia.pdf.

Georgiadou, Christina. 2013. "Towards a 'Re-envisioning of the Everyday' in Refugee Studies.” In Being Human, Being Migrant: Senses of Self and Well-Being, edited by Anne Sigfrid Gronseth, 116-138. New York: Berghahn Books.

Goethe, Johann Wolfgang von. (1819) 1992. "Translations." In Theories of Translation: An Anthology of Essays from Dryden to Derrida, edited by Rainer Schulte and John Biguenet, 60-63. Chicago: The University of Chicago Press.

Harari, Yuval Noah. 2016. Homo Deus: A Brief History of Tomorrow. London: Vintage. hooks, bell. 2015. Yearning: Race, Gender, and Cultural Politics. New York: Routledge.

Ideation Worldwide (IDeA). 2018. Place and Displacement Competition: Integrating Refugee Populations within Cities. Accessed September 24, 2019. http://www.idevelopment.us/2018-results (site discontinued).

Kacmaz Erk, Gul, and Tuna Yilmaz. 2014. "Fatih Akin Filmlerinde Gercekligin Temsili" [Representing Reality in Fatih Akin Films]. Betonart: Beton, Mimarlik ve Tasarim [Betonart: Concrete, Architecture and Design] 41: 54-59. https://betonart.com.tr/dergi/41.

Kacmaz Erk, Gul and Christopher Wilson. 2018. "Framed Memories of Berlin: Film, Remembrance and Architecture." Journal of Architecture and Culture 6 (2): 243-63. https://www.tandfonline.com/doi/full/10.1080/20507828.2018.1478513

Kacmaz Erk, Gul. 2018. "Istanbul Pilot Study" [unpublished synopsis]. School of Natural and Built Environment. Belfast: Queen's University Belfast.

2019. "Everyday Practices and Lived Spaces of Refugee Children on YouTube." Paper presented at CineMuseSpace Conference: Slices of Everyday Lives, September 19-20, 2019. Cambridge: University of Cambridge.

Forthcoming. "Cinema and the Walled City." In Narrating the City: Mediated Representations of Architecture, Urban Forms and Social Life, edited by Aysegul Akcay Kavakoglu, Turkan Nihan Haciomeroglu and Lisa Landrum, Bristol: Intellect Books. https://www.intellectbooks.com/narrating-the-city.

Forthcoming. "Right to a New Home: A Pilot Study of Architectural Filmmaking with Syrian Refugees." In Urban Flows: Issues on Changing Urban Space, edited by Ozlem Erdogdu Erkarslan and Ela Alanyali Aral.

Kazaz, Gozde, and Ilksen Mavituna. 2018. Leaving this Country: The Ones Here and There are Telling the Migration Climate of the New Turkey. Istanbul: Metropolis.

McGartland Rubio, Doris, Ellie Schoenbaum, Linda Lee, David Schteingart, Paul Marantz, Karl Anderson, Lauren Dewey Platt, Adriana Baez and Karin Esposito. 2010. "Defining Translational Research: Implications for Training." Academic Medicine 85 (3): 470475. https://www.ncbi.nlm.nih.gov/pmc/articles/PMC2829707. 
Mitchel, Ciara. 2018. “Architecture of Asylum: Ireland's Direct Provision Centres.” Master's thesis, Master of Architecture, School of Natural and Built Environment. Belfast: Queen's University Belfast.

Queen's Film Theatre. 2017. Walled Cities: Omar. Accessed May 16, 2020. https://queensfilmtheatre.com/Whats-On/Walled-Cities-Omar.

Senator George J. Mitchell Institute for Global Peace, Security and Justice, the. 2018. "Global Conflict: The Human Impact Conference." https:/www.qub.ac.uk/Research/GRI /mitchell-institute/global-conflict-the-human-impact.

Shannon Rusk, Aisling. 2019. "Mouthpieces of the Limit: Liminal Spatial Praxis in Divided and Contested Contexts." PhD diss., Queen's University Belfast.

Sirkeci, Ibrahim. 2018. "Foreword: Migration is Related to Happiness." In Leaving this Country: The Ones Here and There are Telling the Migration Climate of the New Turkey, edited by Gozde Kazaz and Ilksen Mavituna, 7-16. Istanbul: Metropolis.

United Nations High Commissioner for Refugees (UNHCR). 2019. "Trends at a Glance." https://www.unhcr.org/globaltrends2018.

. 2020. “Syria Regional Refugee Response.” http://data.unhcr.org/syrianrefugees.

Yilmaz, Didem Gunes. 2015. "Adaptation to Rural Transformation: A Place-based Investigation into Post-earthquake Permanent Housing Projects in Eastern Turkey." PhD diss., Queen's University Belfast.

\section{ABOUT THE AUTHOR}

Gul Kacmaz Erk: Senior Lecturer (Associate Professor) in Architecture, School of Natural and Built Environment, Queen's University Belfast, Belfast, Northern Ireland, United Kingdom 


\section{The International Journal of Community Diversity}

is one of four thematically focused journals in the family of journals that support the Diversity

Research Network -its journals, book imprint, conference, and online community.

This journal examines the processes of governance and democracy in diverse communities. It explores the consequences of global human movement (e.g., immigrants, refugees) on local communities, and, in response, the development of multicultural policies and practices. It also investigates community self-governance and community capacity development.

As well as papers of a traditional scholarly type, this journal invites case studies that take the form of presentations of diversity practice-including documentation of socially engaged practices and exegeses analyzing the effects of those practices.

The International Journal of Community Diversity is a peer-reviewed, scholarly journal. 